\title{
Criteria approach to assessing the business stability of industrial and energy enterprises
}

\author{
Inessa Lukmanova ${ }^{1,}{ }^{*}$, Aida Kazanbieva ${ }^{2}$, Olga Astafyeva $^{2}$, Natalia $_{\text {Ershova }}{ }^{3}$, Nadezhda \\ Danilochkina $^{4}$, Elena Zubeeva ${ }^{4}$ and Dmitry Prokofiev ${ }^{4}$ \\ ${ }^{1}$ Moscow State University of Civil Engineering, Yaroslavskoeshosse, 26, Moscow, 129337, Russia \\ ${ }^{2}$ State University of Management, Ryazanskiy prospect, 99, Moscow, 109542, Russia \\ ${ }^{3}$ Diplomatic Academy of the Ministry of Foreign Affairs of Russian Federation, Ostozhenka 53/2, \\ Moscow, 119021, Russia \\ ${ }^{4}$ Moscow Aviation Institute, Volokolamskoe highway, 4, Moscow, 125993, Russia
}

\begin{abstract}
The paper presents the results of the study in the field of ensuring the business stability of industrial and energy enterprises by determining the influence of external and internal factors. Identification of stability criteria was carried out by an expert survey using a simple but reliable mathematical apparatus. The final integral indicator of the economic stability of an industrial enterprise was obtained by a calculation and expert method using economic and mathematical modeling. The proposed method is quite universal and can be used to assess the stability of an enterprise over time, as well as to compare the stability of several enterprises with each other.
\end{abstract}

\section{Introduction}

The need to regulate the economic stability of producers is determined both by the need to stimulate its improvement and the need to mitigate the negative effects of the market environment. The implementation of the strategy of stable functioning and development of industrial enterprises requires, first of all, the development of a scientifically based methodology for assessing the level of its economic stability, defining a system of indicators by which factor analysis of stability can be carried out, as well as managing its improvement. The diversity and lack of validity of the proposed indicators complicate the assessment, accounting and analysis, and impede the formation of an effective management system for its improvement.

The process of forming or selecting the most significant indicators can be carried out by the method of expert assessments, since it is impossible to assign quantitative values to a number of factors included in the problem under study using other methods. Therefore, many decisions have to be made with a greater degree of uncertainty and risk. The qualitative nature of the factors under study determines the participation of experts in the measurement process. The task of quantitative measurements of quality indicators can be defined as the task of obtaining and processing expert assessments [1].

\footnotetext{
*Corresponding author: lukmanova@mgsu.ru
} 
There are many methods of conducting an expert survey, the most widely used are the following: the method of individual expert assessment, the interview method, the Delphi method, the heuristic forecasting method, the matrix method, the method of collective generation of ideas and others.

\section{Materials and methods}

From the theory of expert assessment, it is known that an expert can reliably rank objects if their number is not more than ten [2]. Otherwise, the expert should provide the results of pairwise comparison of objects for further processing. Further, the ranking is carried out by constructing tournament brackets and a median of expert rankings.

In order to achieve optimal complexity and efficiency of the expert survey, we have grouped the most significant criteria and factors of economic stability of the enterprise on the basis of the analysis of the stability assessment theory, survey data from the Federal State Statistics Service, and the correlation analysis. The results of the grouping are presented in Table 1.

Table 1. Grouping factors of economic stability of an industrial enterprise for conducting an expert survey.

\begin{tabular}{|c|c|c|c|}
\hline \multicolumn{3}{|c|}{ Internal environment } & \multirow{2}{*}{$\begin{array}{c}\begin{array}{c}\text { External } \\
\text { environment }\end{array} \\
\text { External factors }\end{array}$} \\
\hline Production field & Investment field & Financial field & \\
\hline $\begin{array}{l}\text { Efficiency of management } \\
\text { and organizational activities } \\
X_{1.1}\end{array}$ & $\begin{array}{l}\text { Depreciation } \\
\text { deductions } \mathrm{X}_{2.1}\end{array}$ & $\begin{array}{l}\text { Financial safety } \\
\text { margin } \mathrm{X}_{3.1}\end{array}$ & $\begin{array}{l}\text { The ratio of supply } \\
\text { and demand } \mathrm{X}_{4.1}\end{array}$ \\
\hline $\begin{array}{l}\text { The level of use of } \\
\text { production capacity } \mathrm{X}_{1.2}\end{array}$ & Security loan $X_{2.2}$ & Solvency $\mathrm{X}_{3.2}$ & $\begin{array}{l}\text { State of economy } \\
\mathrm{X}_{4.2}\end{array}$ \\
\hline $\begin{array}{l}\text { Efficiency of the } \\
\text { management apparatus } \mathrm{X}_{1.3}\end{array}$ & Net income $\mathrm{X}_{2.3}$ & $\begin{array}{l}\text { Degree of } \\
\text { financial risk } X_{3.3}\end{array}$ & $\begin{array}{l}\text { Natural and climatic } \\
\text { conditions } \mathrm{X}_{4.3}\end{array}$ \\
\hline $\begin{array}{l}\text { Implementing innovation in } \\
\text { management } X_{1.4}\end{array}$ & $\begin{array}{l}\text { Cost of shares } \\
\mathrm{X}_{2.4}\end{array}$ & $\begin{array}{l}\text { Enterprise own } \\
\text { funds } X_{3.4}\end{array}$ & Tax system $\mathrm{X}_{4.4}$ \\
\hline $\begin{array}{l}\text { Quality and rhythm of use } \\
\text { and consumption of labor } \\
\text { resources and material and } \\
\text { technical resources } X_{1.5}\end{array}$ & $\begin{array}{l}\text { Dividend income } \\
\mathrm{X}_{2.5}\end{array}$ & Liquidity $\mathrm{X}_{3.5}$ & Inflation rate $\mathrm{X}_{4.5}$ \\
\hline $\begin{array}{l}\text { Level of mechanization and } \\
\text { productivity of technical } \\
\text { means of labor and their } \\
\text { qualitative composition } \mathrm{X}_{1.6}\end{array}$ & $\begin{array}{l}\text { Increase in the } \\
\text { value of enterprise } \\
\mathrm{X}_{2.6}\end{array}$ & $\begin{array}{l}\text { Return on equity } \\
\text { of the } \\
\text { organization (total } \\
\text { capital) } X_{3.6}\end{array}$ & $\begin{array}{l}\text { Level of competition } \\
\mathrm{X}_{4.6}\end{array}$ \\
\hline $\begin{array}{l}\text { Degree of stability of } \\
\text { relations with suppliers of } \\
\text { equipment and materials } \\
\text { (payment terms, discounts, } \\
\text { deferments) } X_{1.7}\end{array}$ & $\begin{array}{l}\text { Degree of } \\
\text { investment risk } \\
\mathrm{X}_{2.7}\end{array}$ & $\begin{array}{l}\text { Turnover of fixed } \\
\text { and working } \\
\text { capital } X_{3.7}\end{array}$ & $\begin{array}{l}\text { Level of } \\
\text { development of STP } \\
X_{4.7}\end{array}$ \\
\hline $\begin{array}{l}\text { Qualification of the } \\
\text { production personnel } \mathrm{X}_{1.8}\end{array}$ & & $\begin{array}{l}\text { Level and rhythm } \\
\text { of targeted } \\
\text { funding } \mathrm{X}_{3.8}\end{array}$ & $\begin{array}{l}\text { Investment } \\
\text { attractiveness of the } \\
\text { region } X_{4.8}\end{array}$ \\
\hline $\begin{array}{l}\text { Business value of an } \\
\text { enterprise } X_{1.9}\end{array}$ & & $\begin{array}{l}\text { Coverage of } \\
\text { obligations } X_{3.9}\end{array}$ & $\begin{array}{l}\text { Political stability } \\
\mathrm{X}_{4.9}\end{array}$ \\
\hline $\begin{array}{l}\text { Number of objects built } \\
\mathrm{X}_{1.10}\end{array}$ & & & $\begin{array}{l}\text { Concentration of } \\
\text { investors in the } \\
\text { region } X_{4.10}\end{array}$ \\
\hline
\end{tabular}


A group of experts who are specialists in the field of production, financial and economic analysis, marketing and investing is formed to conduct an expert assessment. The results of the simulated result of the expert survey are presented in Table 1. The average rating is defined as the quotient of the sum of the estimates for the proposal by the number of experts.

Ranks are defined as a sequence of changes in scores (maximum score - rank 1, slightly less score - rank 2, etc.). If the scores of the two events are the same, the rank is defined as the arithmetic average of the ranks. Events that score the minimum amount of ranks are considered to be of the highest priority.

An expert assessment is quite subjective, so it is advisable to determine the degree of reliability of the study. The degree of reliability of expert study can be determined in several ways.

1. If in the process of assessment, quantitative indicators are determined in points, then the coefficient of variation of estimates for each object is calculated [3, 4]. To calculate this coefficient, it is required to determine the average estimate of the proposal, the dispersion, and the standard deviation.

The average score for the $\mathrm{i}$-th object is determined by the formula:

$$
\overline{C_{i j}}=\frac{1}{n} \times \sum_{j=1}^{m} C_{i j}
$$

where $\mathrm{n}$ - number of experts,

$\mathrm{m}$ - number of objects under assessment,

$\mathrm{C}_{\mathrm{ij}}$ - assessment of the $\mathrm{i}$-th object by the expert $\mathrm{j}$,

$\overline{C_{i j}}$ - average score for the i-th object.

The dispersion of scores is determined by the formula:

$$
D_{i}=\frac{1}{n-1} \times \sum_{j=1}^{m}\left(C_{i j}-\overline{C_{i j}}\right)
$$

where $\mathrm{D}_{\mathrm{i}}-$ dispersion of scores.

The coefficient of variation is determined by the formula:

$$
\vartheta_{i}=\frac{\sqrt{D_{i}}}{\overline{C_{i j}}}=\frac{\partial_{i}}{\overline{C_{i j}}}
$$

where $\vartheta_{i}$ - coefficient of variation of scores,

$\partial_{i}$ - standard deviation.

\begin{tabular}{|c|c|c|c|c|c|c|c|c|c|c|c|c|}
\hline \multirow[t]{2}{*}{ Indicators } & \multicolumn{8}{|c|}{ Expert scores } & \multirow{2}{*}{$\begin{array}{l}\text { Average } \\
\text { score }\end{array}$} & \multirow[b]{2}{*}{ Dispersion } & \multirow{2}{*}{$\begin{array}{l}\text { Standard } \\
\text { deviation }\end{array}$} & \multirow{2}{*}{$\begin{array}{c}\text { Coefficient of } \\
\text { variation }\end{array}$} \\
\hline & 1 & 2 & 3 & 4 & 5 & 6 & 7 & 8 & & & & \\
\hline \multicolumn{13}{|l|}{ Production } \\
\hline $\mathrm{X} 1.1$ & 9 & 10 & 8 & 10 & 10 & 10 & 10 & 10 & 9.63 & 0.55 & 0.74 & 0.08 \\
\hline $\mathrm{X} 1.2$ & 9 & 9 & 7 & 9 & 9 & 8 & 6 & 7 & 8.00 & 1.43 & 1.20 & 0.15 \\
\hline $\mathrm{X} 1.3$ & 9 & 9 & 8 & 8 & 9 & 8 & 8 & 8 & 8.38 & 0.27 & 0.52 & 0.06 \\
\hline X1.4 & 8 & 3 & 5 & 5 & 3 & 6 & 8 & 7 & 5.63 & 3.98 & 2.00 & 0.35 \\
\hline $\mathrm{X} 1.5$ & 8 & 7 & 6 & 8 & 8 & 8 & 8 & 9 & 7.75 & 0.79 & 0.89 & 0.11 \\
\hline $\mathrm{X} 1.6$ & 9 & 7 & 6 & 7 & 7 & 6 & 9 & 10 & 7.63 & 2.27 & 1.51 & 0.20 \\
\hline $\mathrm{X} 1.7$ & 7 & 7 & 5 & 7 & 6 & 8 & 7 & 9 & 7.00 & 1.43 & 1.20 & 0.17 \\
\hline $\mathrm{X} 1.8$ & 8 & 8 & 6 & 8 & 7 & 10 & 8 & 8 & 7.88 & 1.27 & 1.13 & 0.14 \\
\hline X1.9 & 8 & 4 & 5 & 7 & 4 & 8 & 10 & 6 & 6.50 & 4.57 & 2.14 & 0.33 \\
\hline $\mathrm{X} 1.10$ & 5 & 6 & 5 & 8 & 8 & 8 & 5 & 5 & 6.25 & 2.21 & 1.49 & 0.24 \\
\hline \multicolumn{13}{|l|}{ Investment } \\
\hline $\mathrm{X} 2.1$ & 4 & 3 & 4 & 4 & 4 & 3 & 6 & 3 & 3.88 & 0.98 & 0.99 & 0.26 \\
\hline
\end{tabular}

In the case when $0<\vartheta_{i}<0.3$, the consistency of experts is considered sufficient.

Table 2. Modeling the results of the consistency of experts by scores. 


\begin{tabular}{|l|c|c|c|c|c|c|c|c|c|c|c|c|}
\hline X2.2 & 7 & 8 & 6 & 8 & 8 & 5 & 7 & 8 & 7.13 & 1.27 & 1.13 & 0.16 \\
\hline X2.3 & 8 & 9 & 8 & 9 & 10 & 7 & 10 & 8 & 8.63 & 1.13 & 1.06 & 0.12 \\
\hline X2.4 & 7 & 3 & 7 & 3 & 2 & 3 & 7 & 4 & 4.50 & 4.57 & 2.14 & 0.48 \\
\hline X2.5 & 7 & 2 & 6 & 2 & 1 & 3 & 7 & 4 & 4.00 & 5.71 & 2.39 & 0.40 \\
\hline X2.6 & 8 & 5 & 6 & 4 & 4 & 5 & 7 & 6 & 5.63 & 1.98 & 1.41 & 0.25 \\
\hline X2.7 & 5 & 6 & 7 & 5 & 6 & 3 & 7 & 8 & 5.88 & 2.41 & 1.55 & 0.26 \\
\hline Finances & & & & & & & & & & & & \\
\hline X3.1 & 8 & 6 & 5 & 8 & 6 & 10 & 9 & 8 & 7.50 & 2.86 & 1.69 & 0.23 \\
\hline X3.2 & 10 & 10 & 7 & 9 & 9 & 10 & 10 & 9 & 9.25 & 1.07 & 1.04 & 0.11 \\
\hline X3.3 & 8 & 6 & 5 & 7 & 4 & 10 & 9 & 7 & 7.00 & 4.00 & 2.00 & 0.29 \\
\hline X3.4 & 9 & 5 & 7 & 7 & 5 & 8 & 10 & 8 & 7.38 & 3.13 & 1.77 & 0.24 \\
\hline X3.5 & 5 & 9 & 6 & 9 & 9 & 8 & 9 & 9 & 8.00 & 2.57 & 1.60 & 0.20 \\
\hline X3.6 & 8 & 8 & 5 & 10 & 10 & 10 & 9 & 8 & 8.50 & 2.86 & 1.69 & 0.20 \\
\hline X3.7 & 8 & 4 & 5 & 5 & 4 & 6 & 8 & 6 & 5.75 & 2.50 & 1.58 & 0.27 \\
\hline X3.8 & 8 & 7 & 5 & 9 & 10 & 8 & 8 & 8 & 7.88 & 2.13 & 1.46 & 0.19 \\
\hline X3.9 & 6 & 9 & 5 & 9 & 9 & 8 & 8 & 8 & 7.75 & 2.21 & 1.49 & 0.19 \\
\hline External & & & & & & & & & & & & \\
environment & & & & & & & & & & & & \\
\hline X4.1 & 7 & 7 & 8 & 9 & 8 & 10 & 8 & 8 & 8.13 & 0.98 & 0.99 & 0.12 \\
\hline X4.2 & 8 & 8 & 7 & 10 & 10 & 10 & 8 & 7 & 8.50 & 1.71 & 1.31 & 0.15 \\
\hline X4.3 & 3 & 1 & 5 & 2 & 1 & 3 & 8 & 5 & 3.50 & 5.71 & 2.39 & 0.38 \\
\hline X4.4 & 4 & 8 & 5 & 8 & 7 & 10 & 9 & 8 & 7.38 & 3.98 & 2.00 & 0.27 \\
\hline X4.5 & 8 & 6 & 6 & 7 & 4 & 10 & 9 & 7 & 7.13 & 3.55 & 1.89 & 0.26 \\
\hline X4.6 & 8 & 4 & 7 & 5 & 3 & 8 & 8 & 7 & 6.25 & 3.93 & 1.98 & 0.32 \\
\hline X4.7 & 6 & 3 & 5 & 4 & 3 & 7 & 5 & 5 & 4.75 & 1.93 & 1.39 & 0.29 \\
\hline X4.8 & 6 & 9 & 5 & 9 & 9 & 10 & 7 & 7 & 7.75 & 3.07 & 1.75 & 0.23 \\
\hline X4.9 & 8 & 4 & 4 & 4 & 1 & 8 & 8 & 5 & 5.25 & 6.50 & 2.55 & 0.39 \\
\hline X4.10 & 9 & 6 & 4 & 6 & 4 & 8 & 8 & 8 & 6.63 & 3.70 & 1.92 & 0.29 \\
\hline
\end{tabular}

2. If the ranks of the indicators are known, it is possible to calculate the general consistency of experts using the formula [5]:

$$
W=\frac{12 \times \sum_{i=1}^{m}\left(S_{i}-\bar{S}\right)^{2}}{n^{2} \times\left(m^{3}-m\right)}
$$

where $\mathrm{S}_{\mathrm{i}}$ - sum of ranks by i-th object,

$\bar{S}$ - average rank.

In the case when $\mathrm{W}=0$, there is a complete inconsistency of experts, when $\mathrm{W}=1$ absolute consistency, if $\mathrm{W} \geq 0.5$, then consistency can be considered sufficient.

Let us define the consistency of experts when ranking indicators for assessing the economic stability of industrial enterprises. For the studied totality of ranks $\bar{S}=43.4$. Then, according to the formula (2.4), $\mathrm{W}=0.57$. This value of the coefficient of general consistency of experts indicates a sufficient level of consistency and, therefore, sufficient accuracy of the conclusions of the expert survey. In the first group of indicators, the value of the concordance coefficient is $\mathrm{W}_{1}=0.58$, in the second group of indicators $-\mathrm{W}_{2}=0.69$, in the third group $-\mathrm{W}_{3}=0.55$, and in the fourth group $-\mathrm{W}_{4}=0.53$.

As a result of the expert survey on the importance of indicators characterizing the economic stability of the enterprise, key indicators of economic stability were selected [6].

The results of the analysis of expert opinions have shown that four groups of indicators characterizing the production, investment, financial, and external components have a cumulative effect on economic stability.

The main, significant criteria in the four analyzed groups of indicators, which together reflect the economic stability of enterprises, are: $\mathrm{X}_{1.1 .}, \mathrm{X}_{1.2 .}, \mathrm{X}_{1.3 .}, \mathrm{X}_{\text {2.2. }}, \mathrm{X}_{\text {2.3., }} \mathrm{X}_{\text {2.6. }}, \mathrm{X}_{\text {3.2. }}$, $X_{\text {3.4., }} X_{\text {3.5. }}, X_{\text {3.6., }}, X_{4.1 .}, X_{4.2 .}, X_{4.4 .}, X_{4.10}$ 
Some indicators, such as the state of the economy, the investment attractiveness of the region, reflect the influence of integral factors on the economic stability of an industrial enterprise. For example, an indicator of the state of the economy can be represented as follows:

$$
\mathrm{SE}=\mathrm{f}\left(\mathrm{GNP}, \mathrm{I}, \sum \mathrm{SI}, \ldots\right)
$$

where SE - indicator of the state of the economy;

GNP - gross national product;

I - inflation, \%;

SI - stock index.

However, with such a view, the calculation of the indicator will be difficult, so we proposed to define this indicator as GDP growth.

\section{Results}

As a result of the analysis of the existing theoretical arsenal, several approaches can be distinguished to find the resultant integral indicator of enterprise assessment (in this case, economic stability).

1. The calculation of the summary indicator by the modified distance method [5]. The calculation is made according to the formula:

$$
R=\sqrt{\sum k_{i}\left(F_{i}-F_{o p t}\right)^{2}},
$$

where $k_{i}$ - weighting factors that characterize the degree of influence of the analyzed ratios on the economic stability of an enterprise,

$\mathrm{F}_{\mathrm{i}}$ - specific values of indicators of the analyzed enterprise,

$\mathrm{F}_{\mathrm{opt}}$ - reference values corresponding to these indicators.

In this method, the weighting factors are determined by the method of expert assessment. The value of such factors is a fairly subjective indicator and reflects only the opinion of an expert or group of experts on this issue.

2. Model for constructing an integral estimate [7]. The integral estimate is obtained from the relation:

$$
R=\sqrt{\sum_{i=1}^{n} \alpha_{i}\left(1-a_{i}\right)^{2}},
$$

where $\alpha_{i}$ - weighting factors of significance of indicators, $\mathrm{a}_{\mathrm{i}}$ is calculated as follows:

$$
a_{i}=\frac{x_{i}}{x_{i}^{\max }}
$$

where $\mathrm{x}_{\mathrm{i}}$ - estimated value of assessment indicator, $x_{i}^{\max }$ - maximum value of the corresponding indicator in the considered totality.

3. Model of difficulty [7]. The integral estimate is determined by the formula:

$$
d=1-\prod_{i=1}^{n}\left(1-d_{i}\right)
$$

where $d_{i}=\frac{\varepsilon_{i}\left(1-a_{i}\right)}{a_{i}\left(1-\varepsilon_{i}\right)}$ - local indicator of the achievement of the difficulty of goal $\mathrm{i}$,

$\varepsilon_{i}$ - threshold value of the indicator $\mathrm{i}, \varepsilon_{i} \leq \mathrm{a}_{\mathrm{i}}$,

$a_{i}=\frac{x_{i}-x_{i}^{\min }}{x_{i}^{\max _{i}^{\min }}}$ - normalization of the indicator $\mathrm{i}$,

$x_{i}^{\max }, x_{i}^{\min }$ - the maximum and minimum value of the $\mathrm{i}$-th indicator in the group of analyzed companies. 
The positive point of this method of obtaining the final assessment is the lack of subjectivity in determining the weighting factors of the influence of the studied factors on the final result. When using this approach, equal participation of all factors in the construction of the rating is ensured. If it is required to compare the assessment results for different models, the model of difficulty is presented in logarithmic form [8]:

$$
Z_{r}=\ln \frac{1}{1-d_{0}}-\ln \frac{1}{1-d}
$$

where $d_{0}$ - fixed value of the difficulty that meets the complete business failure of the organization for all criteria considered.

The value of the rating score in this interpretation tends to the maximum. The complexity of this assessment lies in the choice of criteria for complete business failure of the insurance organization.

4. Point method [8]. In order to formalize the results, a list of criteria in order of importance is compiled, then certain weights are assigned to the assessed indicators, depending on their significance.

The overall score for this system is obtained by multiplying the weights of the ranks by the probability of attaining these ranks and, consequently, obtaining the probability weight of the criterion, which is then multiplied by the weight of the criterion. The data for each criterion is summarized. When using this method, there are a number of problems associated with the subjectivity of assigning weights to indicators.

We have proposed to determine the final integral indicator of the economic stability of an industrial enterprise similar to the point method.

Since the calculated indicators of each group of factors affecting the economic stability of an industrial enterprise have the same dimension, it is proposed to determine the final integral indicator as follows:

$$
\text { Kes }=\sum_{i=1}^{4}\left(\begin{array}{c}
n \\
j=1
\end{array}\right) K^{i j} D^{i}
$$

where $\mathrm{K}_{\mathrm{es}}$ - the economic stability coefficient of an industrial enterprise;

$\mathrm{D}^{\mathrm{i}}$ - the share of influence of the $\mathrm{i}$-th group of factors on the integral indicator of economic stability;

$\mathrm{K}^{\mathrm{ij}}$ - the value of the $\mathrm{j}$-th main significant indicator of the $\mathrm{i}$-th group of factors of economic stability of an industrial enterprise.

The determination of the share of influence of each of the groups of indicators on the resulting integral indicator of the economic stability of the enterprise has been proposed using the formula:

$$
D_{i}=\frac{\sum_{j=1}^{m} \overline{o_{j i}}}{\sum_{i=1}^{n} \sum_{j=1}^{m} \overline{o_{i j}}}
$$

where $D_{i}$ - the share of the influence of the $i$-th group of factors on the integral indicator of economic stability;

$\mathrm{O}_{\mathrm{ij}}$ - the average score of the $\mathrm{j}$-th indicator of the $\mathrm{i}$-th group.

\section{Conclusion}

The coefficient of economic stability of an industrial enterprise, determined by the proposed methodology, can be used both to assess stability over time and to compare the stability of several enterprises.

The implementation of the proposed algorithm will allow an objective assessment of the degree of economic stability of an industrial enterprise, identify and track the dynamics of 
key stability factors, make variant forecasts of enterprise development, and undertake priority measures to ensure stability depending on changes in key factors.

\section{References}

1. V.M. Serov, Stroitel'stvo. Ekonomika i upravlenie 2(24) (2017)

2. Y. Panibratov, A. Larionov, Applied Mechanics and Materials 725 - 726, 1007-1012 (2015)

3. Y. Panibratov, A. Larionov, World Applied Sciences 23,144-148 (2013)

4. A. Larionov, Yu. Larionova, MATEC Web of Conferences 106, 08032 (2017)

5. P.G. Grabovy, A.K. Orlov, Procedia Engineering 153, 195-202 (2016)

6. I. Lukmanova, M. Mishlanova, Bulletin of Irkutsk State Technical University 11, 294299 (2014)

7. R. Golov, T. Narezhnaya, N. Voytolovskiy, V. Mylnik, E. Zubeeva, MATEC Web of Conferences (2018) https://doi.org/10.1051/matecconf/201819305080

8. I. Lukmanova, R. Golov, E3S Web of Conferences 33, (2018) https://doi.org/10.1051/e3sconf/20183302047

9. I. Ilin,, A. Levina, O. Iliashenko, MATEC Web of Conferences, 106, Article number 08066. (2017) doi:10.1051/matecconf/201710608066

10. I. Ilin, S. Shirokova, A. Lepekhin, E3S Web of Conferences, 33, Article number 03007 (2018) doi:10.1051/e3sconf/20183303007

11. L.F. Kazanskaya, O.M. Smirnova. International Journal of Civil Engineering and Technology, 9(11), pp.3006-3012 (2018) 